\title{
Carcinogenic Halogenated Hydrocarbon
}

National Cancer Institute

\section{Source}

National Cancer Institute. Carcinogenic Halogenated Hydrocarbon. NCI Thesaurus. Code C45184.

Molecules with carcinogenic activity that almost entirely consist of carbon and hydrogen that may be cyclic or non-cyclic structures with single, double bonds or both but have at least one halogen element (chloride, bromide, fluoride, iodide, astatine) atom substituted for one of the hydrogen atoms. (NCI05) 